\title{
ОСОБЕННОСТИ ФОРМИРОВАНИЯ ПРОФЕССИОНАЛЬНЫХ ПСИХОЛОГИЧЕСКИХ КОМПЕТЕНЦИЙ В ОБУЧЕНИИ ЮРИСТОВ В СОВРЕМЕННОМ ОБЩЕСТВЕ
}

Интенсивное развитие психологической науки и практики позволяет сегодня широко использовать ее достижения в самых различных областях человеческой деятельности, в частности в образовании и праве.

Вне всякого сомнения, юридическая профессия находится в той сфере человеческой деятельности, где доминирующими являются отношения «человек-человек». Где бы и кем бы ни работал юрист, в какой бы сфере юридической деятельности он ни нашел применения юридическим знаниям, он всегда и везде общается и работает с людьми, будь то обвиняемый или свидетель по уголовному делу, стороны по гражданскому или арбитражному делу, партнеры по бизнесу, коллеги по работе. Кроме того, большинство юристов - это лица, в чьем субординационном или функциональном подчинении находится достаточное количество людей. Казалось бы, при такой ситуации наличие у юриста специальных познаний в области психологии и навыков их использования в сфере профессиональной деятельности просто необходимо.

Объектами профессиональной деятельности выпускников являются: события и действия, имеющие юридическое значение; правовые отношения, возникающие в сфере функционирования государственных институтов; правовые отношения между государственными органами, физическими и юридическими лицами.

Заметим, объектом профессиональной юридической деятельности не назван ни человек, ни личность, ни группа людей, ни общество, ни даже общественные отношения между людьми, а только отношения между абстрактными физическими лицами.

Что должен уметь юрист? Он должен уметь: толковать и применять законы и другие нормативные правовые акты; обеспечивать соблюдение законодательства в деятельности государственных органов, физических и юридических лиц; юридически правильно квалифицировать факты и обстоятельства; разрабатывать документы правового характера, осуществлять правовую экспертизу нормативных актов, давать квалифицированные юридические заключения и консультации; принимать правовые решения и совершать иные юридические действия в точном соответствии с законом; вскрывать и устанавливать факты правонарушений, определять меры ответственности и наказания виновных; предпринимать необходимые меры к восстановлению нарушенных прав; систематически повышать свою профессиональную квалификацию, изучать законодательство и практику его применения, ориентироваться в специальной литературе.

Таким образом, он должен уметь все, но только не работать с людьми, поскольку не они являются объектами его профессиональной деятельности.

Между тем, современное общество предъявляет новые требования к выпускникам юридических факультетов и вузов. Проводимая реформа образования вообще, высшего профессионального в частности и высшего юридического образования в конкретном случае должна проводиться с учетом именно этих новых требований. 
«Одно из направлений модернизации высшего профессионального образования в современный период - это принципиальное изменение концепции государственных образовательных стандартов, переход от гностической концепции и концепции знания стандартов высшего профессионального образования к компетентностному подходу при их формировании» (Коченева 2009: 15).

Отметим, что все компетенции в педагогической науке делятся на ключевые или базовые, которые не связаны с особенностями той или иной профессии, и профессиональные, которые обеспечивают успешную деятельность именно в определенной области профессиональной деятельности.

Остановимся на некоторых из компетенций, в формировании которых основную роль должно сыграть именно психологическое образование. Особенность этих психологических компетенций состоит в том, что они одновременно являются для юриста и базовыми, и профессиональными, иногда даже узкопрофессиональными. Именно в этом заключается их важность и значимость для формирования компетенции будущего юриста.

Для юриста крайне важная профессиональная и ключевая компетенция - это умение и навыки работы в команде. В современной юридической практике командные методы работы приобретают все большую популярность. Создаются оперативные, следственные и оперативно - следственные группы при расследовании сложных многоэпизодных уголовных дел, а таковых становится все больше и больше. Юридическое сопровождение деятельности крупных промышленных предприятий, банков, финансовых групп, корпораций обеспечивается не просто группой юристов, объединенных в юридические отделы, а командой юристов-единомышленников. Командные навыки работы необходимы юристу в процессе разработки нормативных актов, начиная с феде- ральных законов и заканчивая локальными нормативными актами, которые в современной юридической практике имеют не меньшее значение.

Даже адвокаты, стремящиеся в своей практической деятельности к максимальной независимости и максимальному индивидуализму, вынуждены объединяться в группы при осуществлении защиты по крупным уголовным делам или для представительства интересов своих клиентов в судах и иных юрисдикционных органах по крупным гражданским, арбитражным делам.

Между тем в учебных планах юридических факультетов и вузов отсутствуют курсы и дисциплины, способствующие формированию знаний о психике, психологических особенностях личности, навыков работы в команде. Данную компетенцию следует формировать целенаправленно в процессе обучения в учебном заведении, и сделать это можно только на основе знаний в области психологии и с использованием психологических методов.

«Не менее важными являются коммуникативные компетенции юриста. В педагогической литературе коммуникативные компетенции связываются в основном с навыками устной и письменной речи, навыками профессиональной речи и делового профессионального письма, владением иностранными языками. Безусловно, эти составляющие профессиональных компетенций важны для юриста. Но в значительной степени коммуникативные компетенции юриста имеют психологическую составляющую. Именно от них зависит успешность не только межличностного общения выпускника юридического вуза или факультета, но и его успешность в профессиональном общении и профессиональной деятельности'" (Каращук 1988: 72).

Знание психологии людей, с которыми ему придется общаться, психологических особенностей восприятия действительности теми 
или иными субъектами права, особенностей психологического восприятия устной и письменной речи, вербальных и невербальных методов общения могут обеспечить юристу не только получение достоверной и полной информации в процессе допроса того или иного участника процесса, но и успешное ведение и завершение деловых переговоров, заключение сделки на выгодных для клиента условиях и в ряде других видов профессиональной деятельности.

Владение психологическими навыками межличностного и профессионального общения особенно важно для юриста в связи с тем, что в большинстве своем его общение происходит в условиях конфликтной ситуации, в условиях конкуренции между сторонами, а иногда и откровенного противоборства сторон. В этой связи юрист должен выполнять не только свои профессиональные юридические функции, но и функции медиатора, посредника между сторонами по делу, а иногда конфликтолога и психолога одновременно, задача которого - примирить нередко непримиримые интересы сторон.

Для формирования профессиональных и ключевых коммуникативных компетенций юриста необходимо введение таких курсов, как «Общая психология», «Психология общения», «Психология управления», «Психология ведения деловых переговоров», а также проведение тренингов профессионального общения. Именно они позволят будущему юристу установить психологический контакт с людьми независимо от их процессуального, правового, должностного или иного статуса и отношения к собеседнику.

Здесь мы подошли еще к одной профессиональной и базовой компетенции юриста, имеющей психологическую основу формирования, - нервно-психической и эмоциональной устойчивости к конфликтным ситуациям, способности к регуляции и саморегуляции в экст- ремальных условиях. Проблема профессиональной деформации юристов обострилась в последнее время именно по причине отсутствия у большинства юристов данной компетенции.

Текучесть кадров в органах следствия, прокуратуры, МВД, в уголовно-исполнительной системе, в меньшей степени - в судах принято обычно объяснять недостаточным материально-бытовым обеспечением работников этих органов. Между тем это далеко не всегда главная причина. Главная же причина заключается в том, что большинство выпускников вузов не выдерживают экстремальных условий работы, информационной насыщенности юридической практики. Не выдержав этой длительной психотравмирующей ситуации, большинство юристов уходят из следственных органов, органов МВД или прокуратуры в иные более спокойные виды юридической практики или вообще прекращают юридическую практику, едва накопив достаточный для успешной карьеры опыт профессиональной деятельности.

Может быть, именно по этой причине на рынке юридического труда сложилась парадоксальная ситуация: с одной стороны, перепроизводство юристов, а с другой - нехватка грамотных и профессионально состоявшихся юристов во всех органах.

В этих условиях психологическая устойчивость и способность к саморегуляции в экстремальных условиях становятся жизненно значимой компетенцией не только для конкретного юриста, но и для юридической профессии в целом.

Для будущего юриста в современных условиях важны также когнитивные психологические компетенции. Безусловно, успешная профессиональная деятельность юриста во многом определяется объемом его знаний в области психологии. Что же изучается в рамках юридической психологии? «Психология прес- 
тупного поведения. Предмет, основания и поводы для назначения судебно-психологической экспертизы».

Впрочем, повод для такого подхода к формированию психологических знаний юристов дает отчасти само законодательство, «которое ориентирует будущих правоприменителей на то, чтобы наказывать совершенное преступление, а не лицо, его совершившее, расторгать брак, а не разводить конкретных супругов, вершить правосудие, а не судьбы людей, исполнять назначенное по приговору суда наказание, а не исправлять осужденных» (Казанченко 2003: 130).

Между тем правоприменение станет эффективным только тогда, когда в юридической деятельности акценты будут смещены принципиально. Когда юрист будет работать не только с законами и нормативными актами, правоотношениями и юридическими фактами, а с

ЦИТИРОВАННАЯ И УПОМЯНУТАЯ ЛИТЕРАТУРА

1. Казанченко, И.А. (2003). Подготовка юристов к профессиональной деятельности. М. людьми. А для этого юрист должен знать основные закономерности развития личности, понимать связи между психическими феноменами и социальными явлениями, происходящими в обществе, выделять психологические компоненты, определяющие поведение людей в системе правоотношений.

Поэтому важно, чтобы студенты юридических вузов получали знания в области общей и социальной психологии, возрастной и правовой психологии, психологии девиантного поведения и психологии ведения деловых переговоров. Важно вводить практикоориентированные методы обучения, которые характерны для психологического образования, - проведение практических занятий и тренингов, которые бы обеспечивали приобретение студентами не только психологических знаний, но и навыков и умений их использования и применения.

2. Каращук, Л.А. (1988). Психологические особенности профессионального общения юристов. М.

3. Коченова, Н.Б. (2009). О клиническом подходе к гуманизации юридического образования.

\section{ОСОБЕННОСТИ ФОРМИРОВАНИЯ ПРОФЕССИОНАЛЬНЫХ ПСИХОЛОГИЧЕСКИХ КОМПЕТЕНЦИЙ В ОБУЧЕНИИ ЮРИСТОВ В СОВРЕМЕННОМ ОБЩЕСТВЕ}

\section{PEЗЮME}

В статье рассматривается необходимость формирования профессиональных психологических компетенций в обучении юристов в соответствии с новыми требованиями, которые современное общество предъявляет к выпускникам юридических факультетов и вузов. Важно, чтобы студенты юридических вузов получа- ли знания в области общей и социальной психологии, возрастной и правовой психологии, психологии девиантного поведения и психологии ведения деловых переговоров. Важно вводить практикоориентированные методы обучения, которые характерны для психологического образования, - проведение практических 
занятий и тренингов, которые бы обеспечивали приобретение студентами не только психологических знаний, но и навыков и умений их использования и применения.

Ключевые понятия: реформа образования, требования современного общества, мо- дернизация высшего профессионального образования, ключевые и базовые компетенции, формирование психологических знаний, психологическая устойчивость, саморегуляция в профессиональной деятельности.

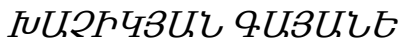

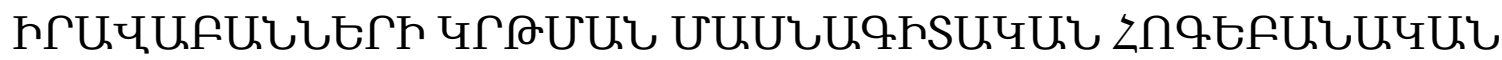

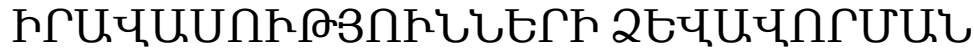

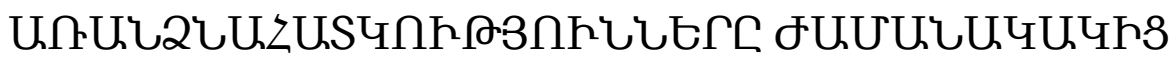

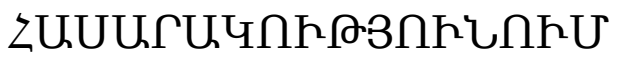

\section{UUФกФกЋU}

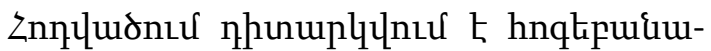

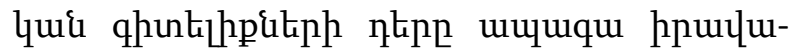

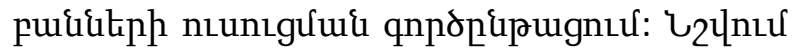

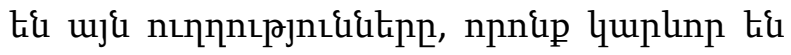

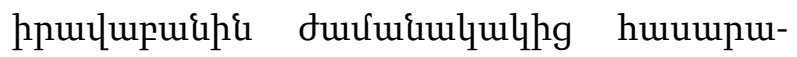

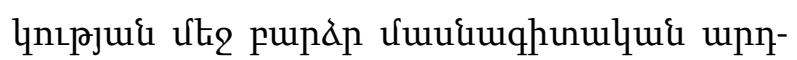

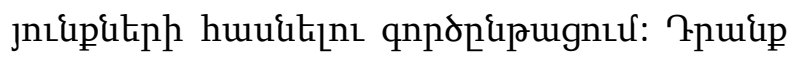
ti` nanhuianın, hpulupuiuuluwi, unghuјuquid hnqtipuinıpjnı\&n:

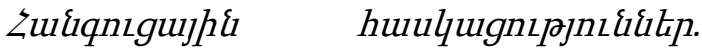

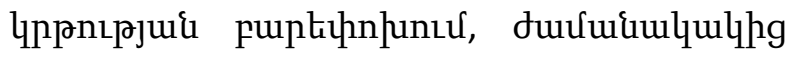

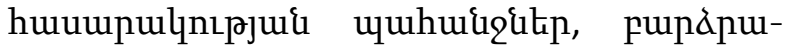

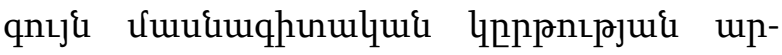

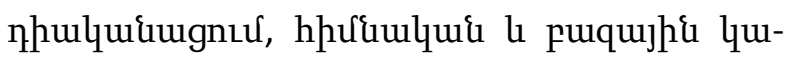

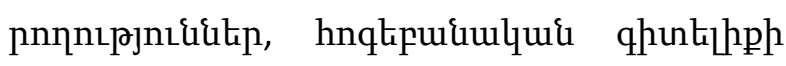

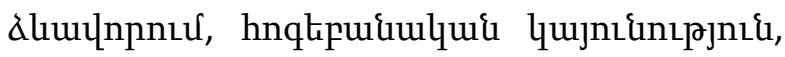

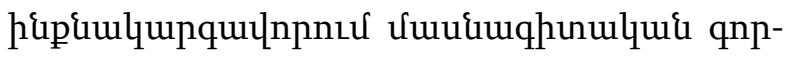

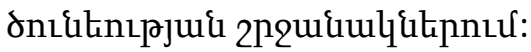

\section{THE SPECIFICS OF THE FORMATION OF THE PROFESSIONAL PSYCHOLOGICAL COMPETENCIES IN TRAINING LAWYERS IN THE MODERN SOCIETY}

\section{SUMMARY}

The article discusses the need of formation of professional psychological competencies in training lawyers according to the new require- ments that modern society places on graduates of law faculties and higher education institutions. It is important that students of legal higher edu- 
cation institutions gain knowledge in the field of general and social psychology, age and legal psy-

Key concepts: education reform, demands of chology, psychology of deviant behavior and psychology of business negotiations. It is essential to introduce practice-oriented teaching methods, which are characteristic of psychological education - implementing practical exercises and trainings that would provide students not only with psychological knowledge, but also skills and competences for their use and application. modern society, modernization of higher education, key and core competencies, formation of psychological knowledge, psychological stability, self-regulation in the professional activity. 